\title{
A Research on the Influence Factors of P2P Lending Market ${ }^{\mathrm{i}}$
}

\author{
Xiaoni Wen, Zhenqi Zhang ${ }^{*}$, Xiaojuan Wu \\ College of Economic and Management, Xidian University, China
}

Copyright $\bigcirc 2017$ by authors, all rights reserved. Authors agree that this article remains permanently open access under the terms of the Creative Commons Attribution License 4.0 International License

\begin{abstract}
The credit platform of P2P network is a new type of lending model which based on Internet technology. It is the inevitable product in the rapid development of science, technology and social economy. It makes the current credit model more diversity and comprehensive, which plays a pivotal role in China's economic development. This paper introduces the mode and characteristics of P2P network lending, as well as the main development of P2P network lending at home and abroad. In this paper, we take the largest P2P network lending website PPDai as an example, using binary logistic regression model to establish a network lending model, researching the factors that affect the success rate of the loan, and carry on the Monte Carlo simulation, to find that credit is an important factor to guarantee the success of P2P transactions. During the period of marketization, compared to traditional finance, P2P network lending model not only has mode innovation but also need to make full use of its advantages of big data, for effective credit and risk assessment. Making outstanding contributions in order to the credit system construction and lending services.
\end{abstract}

Keywords P2P Network Lending, User Behavior, Success Rate of Loan, Credit

\section{Introduction}

With the rapid development of science and technology, the popularization of modern Internet technology has become an irresistible trend. According to the Internet Network Information Center's data in China, in June 30, 2014, the number of Internet users has reached 532 million, mobile phone users in 527 million, the number of sites shows 2.73 million, the number of domain names has reached to 19.15 million. Thus, relying on the Internet technology, financial information will rapidly spread based on low cost.

In the network lending, the users evaluate, filtrate and finally establish, then complete the loan transaction with each other through the Internet technology. In the transaction, it reflects the rapid and convenient everywhere, and it can reduce the cost of the transaction. Moreover, the network lending has a significant effect on resolving the demand of small credit. It can provide funds to entrepreneurs, individual businesses and small businesses for capital turnover and further development which make up the fact that commercial banks usually pay no attention to such group who often difficult obtain funds. At present, P2P network lending has become a representative pattern in this field.

P2P lending market has a rapid development, but faces a lot of problems. The diversity of financial markets also brings threats and challenges to the P2P lending market. From the external, P2P lending platform is still faced with the government regulatory gaps, lack of legal norms, the borrower lack of constraint mechanism, need to regulators to exit the corresponding policy to promote the health industry. From the internal, the low success rate and high borrowing costs, are the mainly problems which restrict the development of the platform. Taking on PPDai as the research object, combined with the site of the latest development trend, analysis the factors in the success of the borrowing, So as to effectively improve the success rate of lending. Combine with the internal mechanism of loan, analyze the results, make network lending platform healthy and have a steady development, adapt to the trend of financial market reform, provide a better service to small and medium-sized enterprises.

\section{Current Situation}

\subsection{Introduction of P2P Lending Market}

$\mathrm{P} 2 \mathrm{P}$ lending (full name Peer-to-Peer lending) is a new mode of personal to personal lending based on Internet. P2P network lending platforms is an intermediary for lenders and borrowers to provide trading places and supplying all kinds of support as a third party. They charge management and related transaction costs of both parties. On P2P lending platform, there is a demand for funds from the borrower, who releases the borrowing requirements and a lender who has investment intentions could do investigation or analysis the 
loan amount, the credit rating, asset strength, financial operations and the possibility of future repayment ability and other indicators of the borrower that provides by the website, then determine the level of interest rates through auction and provide funds to the borrower by the way of credit.

P2P network lending mainly aimed at small and short-term borrowing, provides funds for SMEs, entrepreneurs who are facing financing difficulty or those in urgent need of funds, as a result, financial lending system was supplemented and improved. According to the data in the end of 2012, small and medium micro-enterprises accounted for $81 \%$ of the P2P network lending platform customers. Based on $\mathrm{P} 2 \mathrm{P}$ lending platform, not only can use idle funds to lend borrowers with high credit rating, but also contribute to social resource flows up and rational allocation

\subsection{The Characteristics of P2P Lending Market}

The information is intuitive and transparent. The two parties involved in the transaction can obtain all kinds of real information from P2P lending platform, such as the lender and borrower's real identity, credit rating, funds amount and loan applications of borrowers. Lending transaction can be supervised by website through the borrower's record. It can improve the safety and reliability.

Participants have less restriction. Anyone with borrowing needs or would like to provide funds can become participants in the P2P network lending platform. Fewer restrictions on the amount of the transaction can allocate social funds more flexible and effectively. Trading is mainly targeted at those who cannot meet the commercial bank's credit qualification assessment such as SMEs or low-income groups, and provide funds to meet the need of capital flow, entrepreneurship and so on.

Lending transactions with high efficiency: The transaction in P2P platform by credit lenders was mainly based on the borrower's credit investigation, evaluation and decision-making. Unlike commercial banks, loans always with collateral, but the borrower in P2P platform obtains loans only through their qualifications. At the same time, bases on the advanced Internet technology, makes the transaction and operation process flexible, simple and easy to master. The efficiency of this lending model is much higher than the traditional commercial bank lending.

Coexistence of risks and benefits: On the one hand, borrowers come to P2P network lending mostly because they are "abandoned" by traditional financial institutions, thus switch to P2P network lending, a major factor is the high risk which cannot be ignored. For this reason, in order to obtain funds, the borrowers should pay high interest rates in return.
On the other hand, since two sides are through Internet which is a virtual world, less research done for the authenticity of the information and offline research will cost too much money, there are some risks. Therefore, credit is the key to ensure the success of borrowing.

The characteristics above make P2P network credit platform become the essential complement to modern credit model, makes up the shortage of traditional lending patterns, actively alleviate the increasing loan problem of SMEs and the group of business beginners which meet each group's borrowing needs in whole society, improving the mobility of social resource and effectively using of social idle funds for creating social value, thus promoting the rapid development of economy.

\subsection{Development of P2P Network Lending}

\subsubsection{The foreign development status}

Currently, the global lending platform market is growing rapidly, which has gradually become a competitor to traditional financial patterns. The largest one was established in 2006 named Prosper in the United States, the loan has reached $\$ 170$ million nowadays. As a transaction intermediary, Prosper profit by charging the two transactions sides service fees. In this mode, the borrowers will give the highest interest rates that they are willing to take after Prosper's assessment about their identity, credit and loan term, then lenders with different risk preferences will bid for such loan and borrower and choose the best object ultimately to complete the loan transaction.

To prevent credit risk and determine the lending rates, Prosper lending platform also automatically shows the credit rate to all borrowers: AA, A, B, C, D, E and $\mathrm{HR}$, from high to low, which intend to avoid credit risk, and improve transaction efficiency. Different credit levels have different interest rates and expect loss rates correspondingly.

\subsubsection{The domestic development status}

China conforms to trend of the times either, according to urgent borrowing needs from small business owners and the rapid growth of domestic P2P industry, appears a number of P2P network lending platform, such as PPDai, CreditEase, HongLing Capital. According to the China Electronic Commerce Center statistics, at the end of 2013, the turnover of national P2P network lending reached 87.419 billion Yuan, annual growth rate reached 300 percent, from more than 200 at the end of 2012 to 523 at the end of 2013, the number is expected to grow continually. 
The domestic partial platform Overall Rating Index Table

\begin{tabular}{|c|c|c|c|c|c|}
\hline Name & Volume & Profit & Dispersity & Liquidity & Transparency \\
\hline PPDai & 52.29 & 64.27 & 76.08 & 79.12 & 35.84 \\
\hline HongLing Capital & 63.96 & 55.38 & 32.85 & 100 & 38.19 \\
\hline RRJC & 61.16 & 59.13 & 50.43 & 57.21 & 30.59 \\
\hline RenRenDai & 91.05 & 55.18 & 91.41 & 47.99 & 47.68 \\
\hline
\end{tabular}

Data Sources: WangDaiZhiJia in April 2015 platform Overall Rating Index Table

The most representative one and also the largest scale one is established in 2007, Shanghai, called PPDai, the operation mode mainly imitate the Prosper. In recent years, its operations trading volume totaled reached 400 million Yuan, a total of 1.2 million lenders, and borrowers are over 40,000 . Currently PPDai's monthly trading volumes are around 40 million, the maximum loan amount up to 50 million. According to Great Wall Securities analysis report shows that in 2012 the annual PPDai online transactions exceeded 195 million Yuan, which is 2 times the sum of 2010, 2011 (about 101 million Yuan). In 2012, an annual turnover of transaction is 19729 , bring 770 million management fees. As of the end 2014, PPDai platform has more than 6 million registered users, the successful loan items are over 2.6 million, and cumulatively successful investment amount are more than 12 million.

On the risk prevention, PPDai platform gives the borrower's credit rating for lenders as a reference. On the one hand, PPDai can identify accurately based on the "National Citizen Identity Information System (NCIIS)". On the other hand, participates finish the credit evaluation with each other through the network lending transaction, making credit system complement with each other.

\section{Characteristics of User Behavior}

We know that P2P network lending is lenders and borrowers who use the Internet technology for matching supply and demand of funds. Because of the risks and the characteristics of $\mathrm{P} 2 \mathrm{P}$ network lending platform itself, the transaction is generally small loans, and often credit loans. When the user selects a P2P network lending platform, they tend to choose a mature website with good social media and technical support. It also has the relevant laws and regulation for preventing the leaking of the user's personal information, and insures a security transaction.

\subsection{Characteristics of the Lender's Behavior}

P2P lending platform can meet the demand of people who have idle fund. They can disperse their own funds into small loans for investment by a higher rate rather than the bank deposit interest rate rationally, and get profit by earning interest.

In the network lending, the risk that lenders are taken is greater than that of the borrowers. If the borrower makes a default deliberately, lender will not recover loans. During the repayment period, platform is dunning after the network lending, so lenders need to bear losses themselves. The category rational here means lenders will make a comprehensive analysis and assessment the factors that affect the rate of funds, including: the borrower's credit rating, the purpose of borrowing, loan amount, loan period, repayment, repayment ability and repayment records before making investment decisions. Specifically, the quality of information provided by the borrower will have a significant impact to the decision that lenders make. The borrower who provides information in detail, with timely repayment records of loan, credit has high rating as well as good reputation will expected lender to bear less risk and often favored by lenders and has superiority compared to other borrowers. So the borrowers' behavior and credit evaluation are extremely important.

\subsection{Characteristics of the Borrower's Behavior}

Similar to other forms of borrowing behavior, in P2P network lending, the risk by the borrower is less than the lender, so the main factors that affect the borrowing behavior can be included into three points: the success rate of borrowing, the time and cost of borrowing. Because most of the borrower's loan behavior is due to the shortage of funds which often in an urgent need for turnover, they need P2P lending platform to provide an efficient and timely service.

\section{Research Design}

\subsection{Data Collection and Variable Selection}

Through PPDai to obtain a total of 16189 real transaction data in 2013 to design process (data are anonymous, not involving personal privacy), according to the status of the subject: 7003 bids, the flow of $960(11 \%), 1140(12 \%)$ have been withdrawn, the approval of failure 2209 (24\%), finished $1206(13 \%)$, success 3671 (accounting 40\%) ${ }^{1}$. In this paper, the main research object is the 9186 data that have been completed. In the five states above, "success" and "finished" means successful loan, in the variable processing we will assignment them to 1 , the rest of the three states ("has been withdrawn", "flow", "approval") are assigned to 0 . Therefore, there are only two kinds of variables, successful " 1 ", and unsuccessful " 0 ".

The respective variables and their definitions are shown in table 1.

\footnotetext{
1 Source: PPDai
} 
Table 1. Definition of research variables

\begin{tabular}{|c|c|c|}
\hline Classification & Variation & Variable description \\
\hline \multirow{3}{*}{$\begin{array}{l}\text { Basic loan } \\
\text { factor (Binfo) }\end{array}$} & Amount & $\begin{array}{l}\text { The amount of money borrowed by the } \\
\text { borrower. }\end{array}$ \\
\hline & IR & $\begin{array}{l}\text { The financing cost of the loan by the } \\
\text { borrower }\end{array}$ \\
\hline & Period & Loan period (month) \\
\hline \multirow{6}{*}{$\begin{array}{c}\text { Hard } \\
\text { information } \\
\text { Factor } \\
\text { (Hinfo) }\end{array}$} & Succeed & $\begin{array}{l}\text { The number of users in the past loan } \\
\text { activities to successfully get the money }\end{array}$ \\
\hline & Fail & $\begin{array}{l}\text { The number of times that the user has } \\
\text { not borrowed the money after the loan } \\
\text { is released in the past. }\end{array}$ \\
\hline & Rate & $\begin{array}{l}\text { From HR, E, D, C, B, A were assigned } \\
\text { to } 0,1,2,3,4,5\end{array}$ \\
\hline & $\begin{array}{l}\text { Borrow } \\
\text { Score }\end{array}$ & User as a borrower's credit record \\
\hline & Lend Score & User as a lender's credit record \\
\hline & Numbers & $\begin{array}{l}\text { The borrower issued a number of } \\
\text { projects audit by PPDai }\end{array}$ \\
\hline \multirow{4}{*}{$\begin{array}{c}\text { Soft } \\
\text { information } \\
\text { Factor } \\
\text { (Sinfo) }\end{array}$} & Age & The age of the borrower \\
\hline & Gender & $\begin{array}{l}\text { Male assignment } 1 \text {,female assignment } \\
0\end{array}$ \\
\hline & Marriage & $\begin{array}{l}\text { Married Assignment } 1 \text {, unmarried } \\
\text { assignment } 0\end{array}$ \\
\hline & Education & $\begin{array}{l}\text { From the junior middle school and } \\
\text { below, high school, technical } \\
\text { secondary school, college, } \\
\text { undergraduate, graduate students and } \\
\text { above were assigned to } 0,1,2,3,4,5 \\
\text { without a mortgage Assignment } 1 \text {, } \\
\text { mortgage assignment } 0\end{array}$ \\
\hline
\end{tabular}

\subsection{Model Assumption and Construction}

In this paper, we analyze the data by using Two Logistic Regression to study the effect of multiple independent variables on the dependent variable (loan).

To build a model that can predict the probability of the occurrence of an event relative to a certain event.

$$
P=\frac{\operatorname{Exp}\left(\beta_{0}+\beta_{1} x_{1}+\cdots+\beta_{m} x_{m}\right)}{1+\operatorname{Exp}\left(\beta_{0}+\beta_{1} x_{1}+\cdots+\beta_{m} X_{m}\right)}
$$

Or

$$
P=\frac{1}{1+\operatorname{Exp}\left(-\left(\beta_{0}+\beta_{1} X_{1}+\cdots+\beta_{m} X_{m}\right)\right)}
$$

Where $\beta_{0}$ is a constant term that is independent of the $X_{i}, \beta_{1}, \beta_{2}, \cdots, \beta_{m}$ is the regression coefficient, which indicates that the contribution of the $X_{i}$ to the $P$. If $Q=1-P$, to indicate the probability that an event does not occur, then,

$$
Q=\frac{1}{\operatorname{Exp}\left(\beta_{0}+\beta_{1} X_{1}+\cdots+\beta_{m} X_{m}\right.}
$$

And

$$
\ln \left(\frac{P}{Q}\right)=\beta_{0}+\beta_{1} X_{1}+\cdots+\beta_{m} X_{m}
$$

From the (4) above, the logit transform has a linear function of the $\beta_{0}, \beta_{1}, \cdots, \beta_{m}$.

It shows that the parameters of the Logistic regression model (1) fitted with two categorical variables are converted to the parameters of the fitted linear model (4).

The regression model assumption established in this paper is based on the combination of basic borrowing factors, hard information and soft information. Specific regression models are as follows:

$$
\begin{aligned}
Z= & \ln \left(\frac{P(Y=1)}{P(Y=0)}\right)=C+B \cdot B \inf o+ \\
& +H \cdot H \inf o+S \cdot S \inf o+\varepsilon
\end{aligned}
$$

Where $C$ to intercept vector, $B$ inf $O$ as the basic loan factors, $H$ inf $O$ for hard variables, $S$ inf $O$ soft variable factors, $B, H, S$ were the coefficient vector, $\varepsilon$ represents the model error.

\subsection{Lender Behavior Analysis}

In this analysis, the loan which succeed is the dependent variable, and the other part are independent variable, because the loan amount and loan credit value is large, the analysis process is abnormal, so we use the logarithm to narrow the range and reduce the influence of the abnormal value. The selection of explanatory variables is based on the conditional parameter estimation (Forward: conditional), and Forward Selection method.

Table 2 shows the results of the log likelihood ratio chi square test for the regression equation. Mode $\chi^{2}=7128.368$, Sig values are less than 0.05 . According to the standard $\alpha=0.05$, it can be considered that the 9 independent variables and the dependent variable Logistic regression equation are statistically significant, and the model is effective.

Table 2. Comprehensive test of model coefficients

\begin{tabular}{cccc}
\hline Step 1 steps & 4877.907 & df & Sig. \\
Block & 4877.907 & 1 & .000 \\
Model & 4877.907 & 1 & .000 \\
$\ldots \ldots$ & $\ldots \ldots$ & $\ldots \ldots$ & .000 \\
Step 8 steps & 16.288 & 1 & $\ldots \ldots$ \\
Block & 7123.587 & 8 & .000 \\
Model & 7123.587 & 8 & .000 \\
Step 9 steps & 4.781 & 1 & .000 \\
Block & 7128.368 & 9 & .029 \\
Model & 7128.368 & 9 & .000 \\
\hline
\end{tabular}

Table 3 lists the cross tables of observed values and predicted values. In the data of the model, the state is " 0 " 
(that is, the loan is not successful). The correct rate is $93.1 \%$, and the state is "1"(borrowing success). The correct rate is $88.4 \%$, the correct rate of return to the whole data is $90.7 \%$, which shows that the model is good, and the model is relatively stable.

Table 3. Classification table

\begin{tabular}{|c|c|c|c|}
\hline \multirow{3}{*}{ Observed } & \multicolumn{3}{|c|}{ Observed } \\
\hline & \multicolumn{2}{|c|}{ State } & \multirow{2}{*}{$\begin{array}{l}\text { Percentage } \\
\text { correction }\end{array}$} \\
\hline & 0 & 1 & \\
\hline Step 9 state 0 & 3751 & 279 & 93.1 \\
\hline 1 & 466 & 3537 & 88.4 \\
\hline Total percentage & & & 90.7 \\
\hline
\end{tabular}

a. cutting value is. 500

Regression results are obtained by data processing and model checking, as shown in table 4 . From the table, we find that the Sig value of all the variables is less than 0.05 under the condition of significant level of 0.05 , which shows that these 9 variables have a significant effect on the success of the loan. The probability of a successful loan is:

$$
P=\frac{1}{1+e^{-\left(\beta_{0}+\beta_{1} x_{1}+\beta_{2} x_{2}+\cdots+\beta_{9} x_{9}\right)}}
$$

According to the results of the regression, order,

$$
\begin{gathered}
Z=0.311 \text { Amount }-6.617 \text { IR }+0.256 \text { Gender }- \\
-0.431 \text { House }+0.283 \text { Succeed } \\
-0.572 \text { Fai } 1+0.025 \text { Borrow }+0.344 \text { Lend } \\
+0.093 \text { Number }-4.052
\end{gathered}
$$

Then, the success probability of borrowing is

$$
P=\frac{1}{1+e^{-Z}}
$$

Table 4. Regression results of the model

\begin{tabular}{ccccccc}
\hline & B & S.E, & Wals & df & Sig. & $\begin{array}{c}\text { Exp } \\
\text { (B) }\end{array}$ \\
$\begin{array}{c}\text { Step 9i } \\
\text { The }\end{array}$ & .311 & .081 & 14.771 & 1 & .000 & 1.365 \\
$\begin{array}{c}\text { logarithm } \\
\text { of amount } \\
\text { Interest } \\
\text { rate }\end{array}$ & -6.617 & 1.739 & 14.486 & 1 & .000 & .001 \\
$\begin{array}{c}\text { Gender } \\
\text { Housing } \\
\text { situation }\end{array}$ & .256 & .118 & 4.707 & 1 & .030 & 1.291 \\
$\begin{array}{c}\text { Number of } \\
\text { success }\end{array}$ & .283 & .020 & 205.297 & 1 & .000 & 1.327 \\
$\begin{array}{c}\text { Failure } \\
\text { times }\end{array}$ & -.572 & .024 & 576.820 & 1 & .000 & .564 \\
$\begin{array}{c}\text { Borrowed } \\
\text { credit }\end{array}$ & .025 & .003 & 56.464 & 1 & .000 & 1.026 \\
$\begin{array}{c}\text { The } \\
\text { logarithm } \\
\text { of lending }\end{array}$ & .344 & .046 & 56.867 & 1 & .000 & 1.410 \\
$\begin{array}{c}\text { Audit item } \\
\text { number } \\
\text { Constant }\end{array}$ & .093 & .013 & 49.876 & 1 & .000 & 1.097 \\
\hline
\end{tabular}

\subsection{Monte Carlo Simulation}

Ball crystal software is used to estimate the success rate of the loan, the number of the simulation is 5000 times, the success rate of the loan is obtained by the statistical distribution map (Figure 1) and the rate of success of the loan to the sensitivity of the explanatory variables (Figure 2).

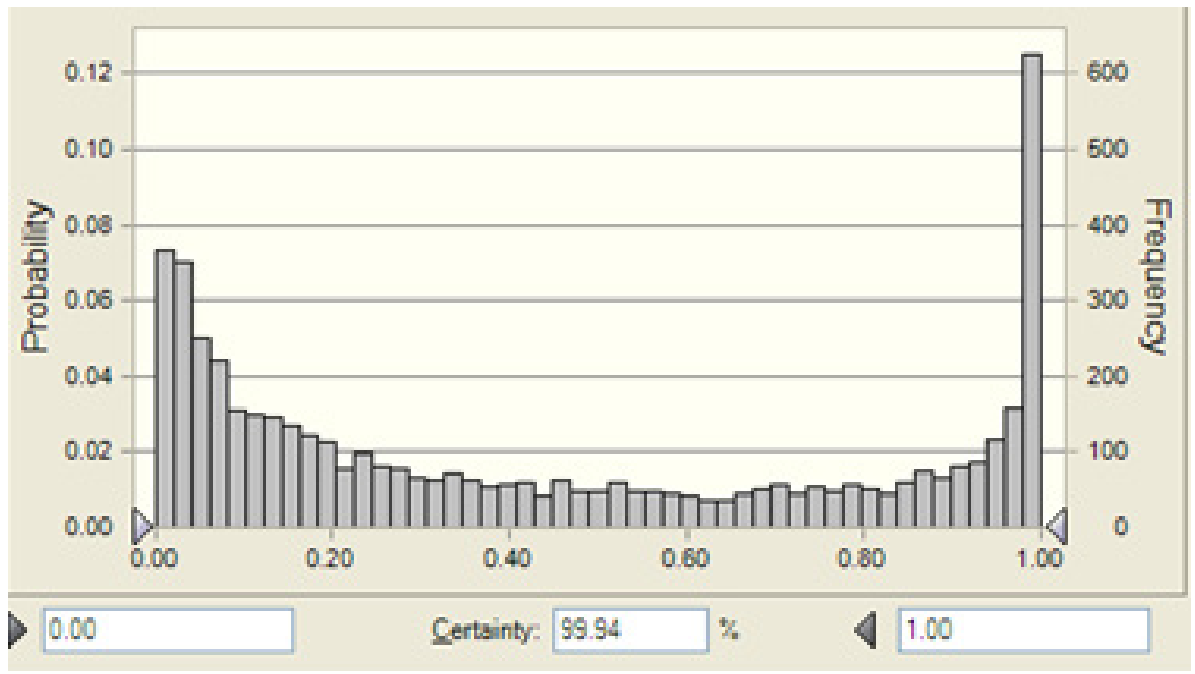

Figure 1. The success rate of loan statistics 


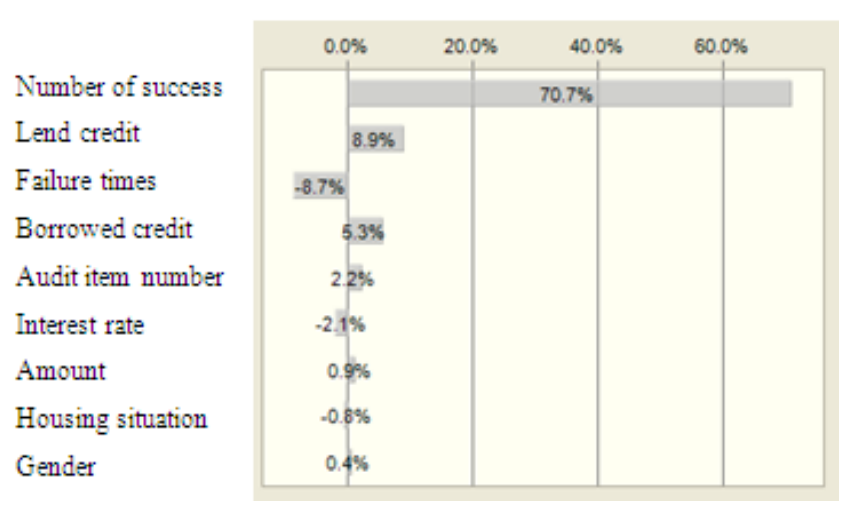

Figure 2. The success rate of the loan to explain the sensitivity of variable

The simulation results in figure $41.10 \%$ is more than 0.5 , the average value of 5000 simulation data is 0.44 , which shows the turnover rate is not very high, only the continuous optimization of the platform, the full use of the information data generated by the platform to further increase the user's trust, improve the trading volume of the platform. Figure 2 shows the success of the number of users of the loan, the number of failures, credit is the score on the success of the loan. In this way, we should pay more attention to the accumulation of credit score and the number of historical transactions in the course of the loan.

\section{Analysis of the Regression Results}

First of all the basic borrowing factor (Binfo), the rate of the coefficient is -6.617 , in the formula, interest rate increase and the success rate of loan is the reverse relationship, which is different from previous scholars. We will study the sample according to the interest rate of two categories, interest rates higher than the average value of $5794,27.67 \%$ of the successful borrowers; interest rates lower than the average of $3392,96.52 \%$ of the borrower's success, which is consistent with the results of the model analysis. This paper analyzes the main reasons that impact on the mechanism of PPDai, compared with the traditional financial institutions, the cost of the borrower's default, if the cost is high, it means that the borrower can assume a higher loan amount, will be more valued personal credit. According to the accumulation of a large data sites, through the borrower in social networking sites, microblogging, micro channel behavior and relationship to assess the cost of who break the contract, the corresponding assessment of the borrower's credit rating, and then given the amount of loans and the borrower's interest rates. So the low credit level of the user, the higher the loan interest rate, and the lower success rate of the loan. On the other hand, the average interest rate of the sample data in each term compared with the average interest rate in the second half of 2013, as shown in Table 5. As an investor, the high return rate of $\mathrm{P} 2 \mathrm{P}$ platform has a lot appeal, therefore more value for the security of funds, high interest rates along with high risk relatively. With the development of the
Internet, the network is becoming more and more diversified investment channels, investors in risk neutral may be more inclined to moderate interest rates, the risk of investment products. The coefficients of the loan amount is 0.311 , a positive effect on the results of borrowing, consistent with the scholars research results before (Dongyu Chen, 201277), because the user's credit rate is high in the platform, and through the examination of the data, more comprehensive and truly, the platform will be a corresponding increase in the loan amount and the possibility of full scale borrowing is also more and more high. In addition, the study shows that the loan period of the loan is not affected, the loan is mainly contributed to the small short-term loans, and the use of risk diversification mechanism, each investor can simultaneously participate in a number of investment, each subject can also have a number of investors, such as capital less tender, to a certain extent, reduce the interest of investors in the period of interest.

Table 5. The average interest rate of the loan and the comparison of SHIBOR in the second half of 2013

\begin{tabular}{ccccc}
\hline & March & June & September & Year \\
\hline PPDai & 20.08 & 10.56 & 15.95 & 16.67 \\
SHIBOR & 4.84 & 4.27 & 4.32 & 4.44 \\
Ratio & 4.15 & 2.47 & 3.69 & 3.75 \\
\hline
\end{tabular}

Data source: PPDai, China currency network

In the "hard information" factor, the number of history success, credit, loan, the number of audit projects on the success of the loan is positive, in this paper, we consider the more successful users, the higher the credit score and the credit score is, to give investors more positive feedback, and believe that the user is active in the loan, and a strong financial strength is relative safety of the loan. And the more audit projects, will provide investors with more information on the borrower. Thus the more effective in reducing information asymmetry, to a certain extent, it is conducive to the success of the loan. The coefficient in the number of historical failures is negative, for -0.572 , which is consistent with the results of previous scholars, the number of users have failure ago, the credit is not good, so more incentive to PPDai users in accordance with the provisions of the timely repayment, and the loan process in accordance with the requirements of the platform to provide the appropriate audit information, otherwise it is easy to cause the flow.

Finally, in the aspect of "soft information", the "soft information" of the model has a gender and residential situation, the age, marital status and education situation. Among them, the gender factor of 0.256 , indicating that the PPDai lending process is easier to males borrow funds, because the users are mostly male, sample accounting for nearly 85 percent of male users; The coefficient of the housing situation is -0.431 , which shows that the user's home mortgage loans will be helpful to the borrower, this paper thinks that the mortgage payment users in the banking system will make it easier for investors to believe in the 
authenticity of the identity. Thus tending to invest in it. In addition, the analysis showed that the age, education status and marital status of the borrower had little effect on the results of the loan.

\section{Summary}

At present, the rapid development of $\mathrm{P} 2 \mathrm{P}$ network lending model as a lending agency has been a seat in the credit market. It is the product with the rapid development of modern technology, which reflects the demand of the user to the diversification of the loan, and makes up the deficiency of the traditional credit model.

In this paper, we analyze the transaction data of the PPDai through binary logistic regression, and use ball crystal software to simulate the final model, From the result analysis, we can see that the loan interest rate and the historical failure number of the borrower have negative effect on the success rate of the loan, but the loan amount, the number of the borrower's history, credit score and the number of audit items have positive effect on the loan. At the same time, the sex of the borrower, the housing situation is also affected the result of the borrower. In addition, this paper select the part of the transaction data as the research object, with the rapid development of Internet, the data flow of the Internet, the data of the P2P network lending platform provides the dynamic information. How important is this information to find the basic, can predict the risk of fraud and early warn the information in credit risk. Thus, through data mining and statistical analysis of data to explore the characteristics and laws, to evaluate the risk, to estimate credit. In the process of financial market reformation, P2P network lending with its concept and technology changes the traditional financial system, and lets the development of the lending platform make outstanding contributions.

\section{REFERENCES}

[1] Iyer, R., Khwaja, A.I., Luttmer, E.F., and Shue, K., 2009. Screening in New Credit Markets: Can Individual Lenders Infer Borrower Creditworthiness in Peer-to-Peer Lending?[R].
National Bureau of Economic Research No.w15242.

[2] Martina E. Greiner, H.W. The Role of Social Capitalin People-to-People Lending Marketplaces[R]. In Thirtieth International Conference on Information Systems. Paper 29. 2009.

[3] Michal Herzenstein, U.M.D., Rick Andrews Strategic Herding Behavior in Peer-to-Peer Loan Auctions[R].Working paper. University of Delaware 2010.

[4] Xiaoying Wu, Ying Jv, 2013. Lending to network model based on least square method[J]. Journal of Xiamen University 51(6): 980-984.

[5] Yixian Mo, 2011. P2P lending, theory and practice at home and abroad. Financial Theory \& Practice 12.

[6] Zhongxian Lin, 2013. The development of the small P2P network credit in our country. Financial technology era 3:99-101.

[7] DongYu Chen, Weijun Li, Jie Ding, 2012. Network loan borrowers decision aid model[J]. Jilin university journals 30(6) : 591-598.

[8] Wangjin Yue,2004. Trust the academic concept of a pair of trust research of examination of several paths. Social Sciences in Nanjing 6:19-24.

[9] Greiner, M.E., Wang, H., 2010. Building Consumer-to-Consumer Trust in E-Finance Marketplaces: An Empirical Analysis[J]. International Journal of Electronic Commerce, 15(2): 105-136.

[10] Lin, M., Prabhala, N.R., Viswanathan, S., 2012. Judging Borrowers by the Company They Keep: Social Networks and Adverse Selection in Online Peer-to-Peer Lending[J]. Management Sci. 59(1):17-35.

[11] Collier, B.C.,Hampshire, R., 2010. Sending Mixed Signals: Multilevel Reputation Effects in Peer-to-Peer Lending Markets[C]//Proceedings of the 2010 ACM Conference on Computer Supported Cooperative Work. ACM, (2):197-206.

[12] Puro, L., Teich, J.E., Wallenius, H., et al, 2010. Borrower Decision Aid for People-to-People Lending[J]. Decision Support Systems, 49(1): 52-60.

[13] Everett, C., 2010.Group Membership, Relationship Banking and Loan Default Risk: the Case of Online Social Lending[J/OL]. http://ssrn.com/abstract=1114428.

[14] Lopez, S.H., 2009. Social Interactions in P2P Lending $[\mathrm{C}] / /$ Proceedings of the 3rd Workshop on Social Network Mining and Analysis. ACM, (6): 3.
iFund project: The shaanxi provincial institute of finance: The research of the development in financial support with science and technology innovation driven economy, 2016; Xi'an science and technology projects: Xi'an high-tech enterprise development with science and technology insurance research, 2014. Science and Technology Department of Shaanxi Province: Research on the mechanism of science and technology financial innovation, 2016 . 